\title{
Reversible nicotinamide-deficiency encephalopathy in a patient with jejunal diverticulosis
}

\author{
S. TABAQCHALI AND C. PALLIS \\ From the MRC Intestinal Malabsorption Research Group and the Department of Medicine, Royal \\ Postgraduate Medical School, Du Cane Road, London W12
}

SUMMARY A patient with severe malabsorption due to massive diverticulosis of the small intestine developed an acute encephalopathic syndrome which responded dramatically to $\frac{\not}{8}$ intravenous nicotinamide. Various mechanisms are discussed whereby nicotinamide deficiency might have occurred in this clinical context.

Neurological symptoms due to nicotinic acid deficiency are uncommon in patients with intestinal disorders. In this communication we describe a patient with extensive jejunal diverticulosis and bacterial overgrowth in the small intestine who developed a severe encephalopathy of the type described in nicotinamide deficiency (Cleckley, Sydenstricker, and Geeslin, 1939; Jolliffe, Bowman, Rosenblum, and Fein, 1940; Spillane, 1947). The neurological disorder responded dramatically to intravenous nicotinamide. Although we can only hint at mechanisms whereby nicotinamide deficiency might have been precipitated, the therapeutic implications are important enough to warrant drawing attention to this unusual occurrence.

\section{Case Report}

Early in 1965 a 66-year-old woman who was a teetotaller and ate a normal diet developed episodic diarrhoea and lost $9 \mathrm{~kg}$ in weight. She remained fairly well, however, until early 1967 when for the first time she noticed pale, bulky stools and ankle oedema. She was admitted to Hammersmith Hospital for investigation in September 1967.

Clinical examination revealed a thin, pale, apathetic woman, weighing $51 \mathrm{~kg}$. The hair was sparse and the skin atrophic. There was no rash, icterus, glossitis, or angular stomatitis. The feet were oedematous and there was moderate ascites.

Received for publication 16 July 1970
The heart was normal and the venous pressure was not raised. No abdominal viscera were palpable. The bones were not tender. There were $\frac{0}{\varnothing}$ no abnormal neurological signs, in particular no suggestion of encephalopathy, myelopathy, or peripheral neuropathy.

\section{HAEMATOLOGICAL INVESTIGATIONS}

The patient was anaemic. The haemoglobin was $10.6 \mathrm{~g} / 100 \mathrm{ml}$, serum iron was $120 \mu \mathrm{g} / 100 \mathrm{ml}, \underline{3}$ serum $B_{12}$ was $260 \mathrm{pg} / \mathrm{ml}$ (normal is in the range $\delta$ $160-960 \mathrm{pg} / \mathrm{ml}$ ), and serum folate was $17 \mathrm{ng} / \mathrm{ml}$ (normal: $3-17 \mathrm{ng} / \mathrm{ml}$ ). Despite the normal levels o of vitamin $B_{12}$ and folic acid in the serum, the blood film showed occasional macrocytes and target cells and the marrow showed mild megaloblastic changes. Similar findings have been re- $\sigma$ ported by Hines, Hoffbrand, and Mollin (1967) $N$ in a patient with jejunal diverticulosis.

BIOCHEMICAL INVESTIGATIONS

Urea was $24 \mathrm{mg} / 100 \mathrm{ml}$. Electrolytes (in m-equiv/l) $\mathrm{Na} 135, \mathrm{~K} \mathrm{3} \cdot 8, \mathrm{Cl} 102, \mathrm{HCO}_{3} 24, \mathrm{Ca} 4 \cdot 5, \mathrm{P} 1 \cdot 4$, $\mathrm{O}$ and $\mathrm{Mg} \mathrm{1 \cdot 6}$. Total plasma protein was $4.8 \mathrm{~g} / 100$ $\mathrm{ml}$ (albumin was $2 \cdot 1 \mathrm{~g} / 100 \mathrm{ml}$ and globulin was $\stackrel{\varnothing}{\varnothing}$ $2.7 \mathrm{~g} / 100 \mathrm{ml}$ ). Bilirubin was $0.9 \mathrm{mg} / 100 \mathrm{ml}$, $\stackrel{\mathbb{Q}}{\stackrel{\circ}{\circ}}$ alkaline phosphatase was $19 \mathrm{KA}$ units $/ 100 \mathrm{ml}$, 5-nucleotidase was $4 \mathrm{IU} / 100 \mathrm{ml}$, isocitric dehydrogenase was $8 \mathrm{IU} / 100 \mathrm{ml}$, cholesterol was 응 $70 \mathrm{mg} / 100 \mathrm{ml}$, and bromsulphthalein retention was $19 \%$ at 45 minutes. Figlu test: Figlu: $O$ and $\frac{\bar{\sigma}}{7}$ mean urocanic acid was $45 \mathrm{mg} / 8 \mathrm{hr}$. 
GASTROINTESTINAL INVESTIGATIONS

Acid secretion in the stomach was tested by the intravenous gastrin infusion method. There was complete achlorhydria.

Pancreatic function tests revealed exocrine pancreatic enzyme deficiency. The mean tryptic activity of the duodenal fluid following a Lundh test meal was 1.5 units $/ \mathrm{ml}$ (normal $>9.6$ units $/ \mathrm{ml}$ ). The 24-hour urinary iso-amylase pattern was characteristic of pancreatic insufficiency (Hobbs and Aw, 1968).

Barium meal and follow-through showed extensive duodenal and jejunal diverticulosis. Barium enema showed a few scattered diverticula in the sigmoid colon but no other lesion. Jejunal biopsy showed normal mucosal pattern under the light microscope.

\section{Absorption studies}

There was steatorrhoea and creatorrhoea. Faecal fat was $27 \mathrm{~g} /$ day $(\mathbf{N}<5)$ and faecal nitrogen was $3.5 \mathrm{~g} /$ day $(\mathrm{N}<2)$ on an intake of $70 \mathrm{~g}$ fat and $70 \mathrm{~g}$ protein. There was malabsorption of xylose, the urinary excretion after a $25 \mathrm{~g}$ oral dose being $3.3 \mathrm{~g} / 5 \mathrm{hr}(\mathrm{N}>5)$. Vitamin $\mathrm{B}_{12}$ absorption was tested using the Schilling test. One $\mu \mathrm{g}$ of ${ }^{58} \mathrm{Co}$ vitamin $B_{12}$ was given together with $20 \mathrm{mg}$ hog intrinsic factor and the urinary excretion was subnormal $(3 \cdot 3 \%$ in 24 hours, $\mathrm{N}>10 \%)$.

\section{Evidence of bacterial overgrowth}

Culture of fasting upper jejunal fluid revealed massive bacterial overgrowth. There was a mixed flora of Esch. coli $\left(10^{8}\right)$, Bacteroides $\left(10^{8}\right)$, aerobic and anaerobic Lactobacilli $\left(10^{7}\right)$, and Streptococci $\left(10^{7}\right.$ organisms $\left./ \mathrm{ml}\right)$.

\section{Bile salt metabolism}

Thin-layer chromatography of the fasting jejunal aspirates revealed evidence of bile salt deconjugation. Free bile acids, not normally found in jejunal fluid, were present $(2.4$ mmoles per litre). The concentration of the conjugated bile salts ( 0.4 mmoles per litre) was very much reduced (normal is in the range $5-10$ mmoles per litre) (Tabaqchali, Hatzioannou, and Booth, 1968).

\section{Serum bile acid pattern}

This was also abnormal. The total concentration of bile acids was increased ( $15.9 \mu$ moles/l). This was mainly due to the abnormal presence $(11.4 \mu$ moles/1) of free bile acids (normal range is $2 \cdot 2-4 \cdot 2$ $\mu$ moles/l, all conjugated) (Lewis, Panveliwalla, Tabaqchali, and Wootton, 1969).

\section{Urinary indican excretion}

This was normal ( $52 \mathrm{mg} / 24$ hours) despite the high bacterial counts in the jejunum and was possibly due to the associated pancreatic insufficiency (Fordtran, Scroggie, and Polter, 1964).

BONE INVESTIGATIONS

A radiological skeletal survey showed under- mineralized bones, but no evidence of pseudofractures. Bone biopsy from the iliac crest showed widened osteoid seams characteristic of osteomalacia.

\section{TREATMENT AND PROGRESS}

These investigations demonstrated that the patient was suffering from extensive jejunal diverticulosis, steatorrhoea, megaloblastic anaemia, hypoproteinaemia with oedema, and osteomalacia. Abnormalities of hepatic and pancreatic function were also present.

She was treated with intravenous albumin infusions (25 $\mathrm{g}$ salt-free albumin daily for one week) in an attempt to correct the hypoalbuminaemia and to reverse the absorptive defects associated with protein malnutrition (Neale, Antcliff, Welbourn, Mollin, and Booth, 1967). The oedema subsided and an improvement in the hepatic and pancreatic function tests suggested that these abnormalities were secondary to the protein malnutrition. Following treatment the urinary indican excretion rose to $170 \mathrm{mg}$ per 24 hours.

The patient then developed pneumonia which was treated with intramuscular penicillin ( 3 mega units daily) and streptomycin (500 mg daily). She was also given tetracycline $(250 \mathrm{mg}$ every s. hours orally) for 10 days and intravenous Parenterovite. There was a reduction in the jejunal bacterial count, free bile acids disappeared from the jejunal fluid, and the faecal fat excretion and vitamin $B_{12}$ absorption returned to normal levels. At the same time the haemoglobin rose and the sternal marrow became normoblastic (Table).

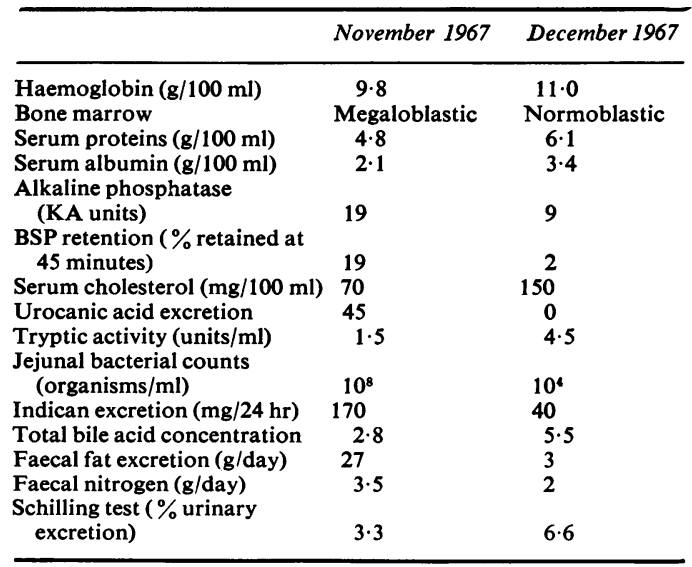

Table Laboratory findings before and after treatment with intravenous albumin and antibiotics

The patient was discharged home in the middle of December and remained well and ambulant for three weeks. Early in January 1968 she had to be readmitted to hospital because of rapid deterioration in her general condition and level of consciousness. She had become stuporous over a 


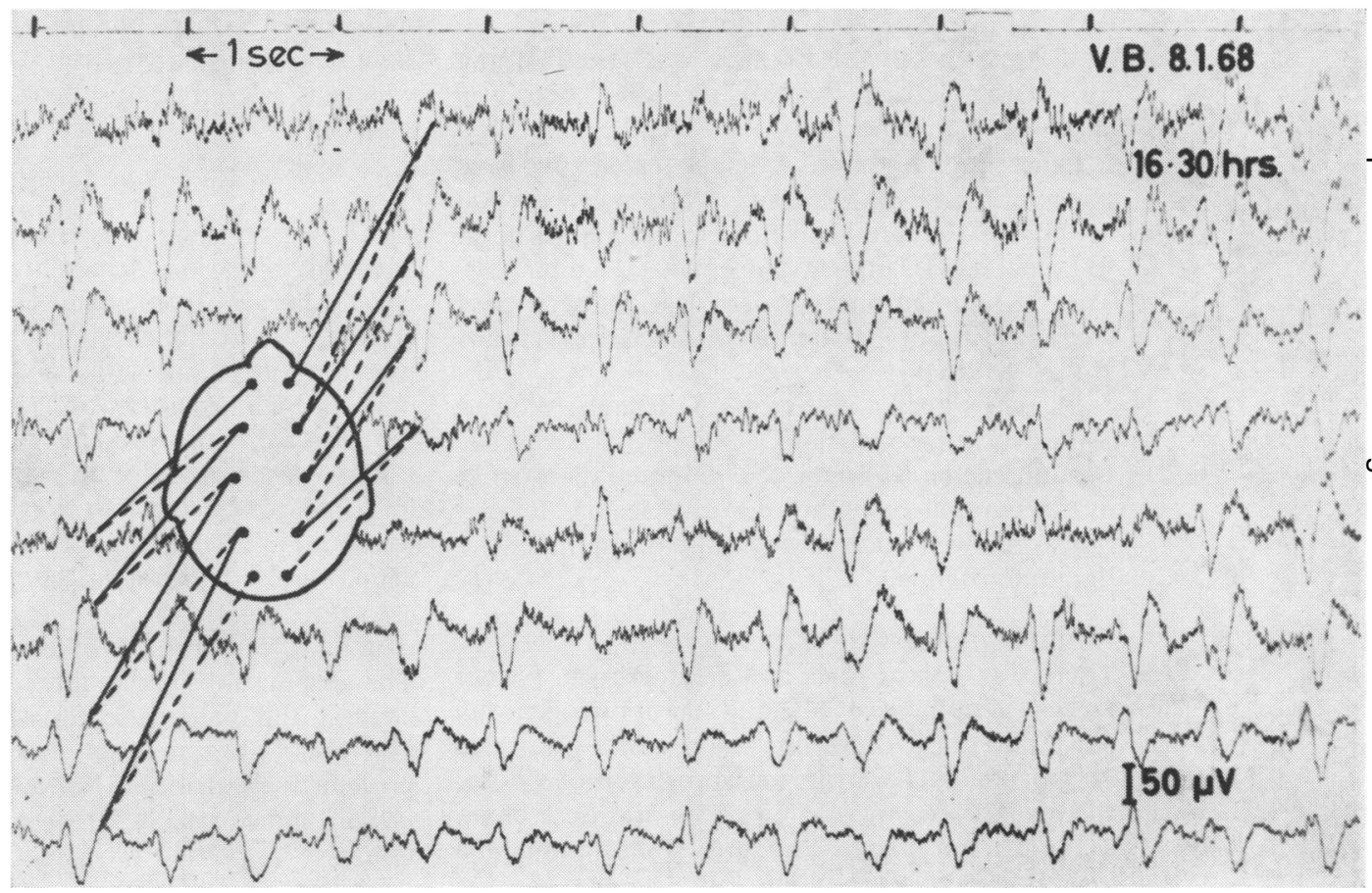

Fig. 1 Record dominated by diffuse, symmetrical, and rhythmically repetitive sharp waves, many of which are triphasic.

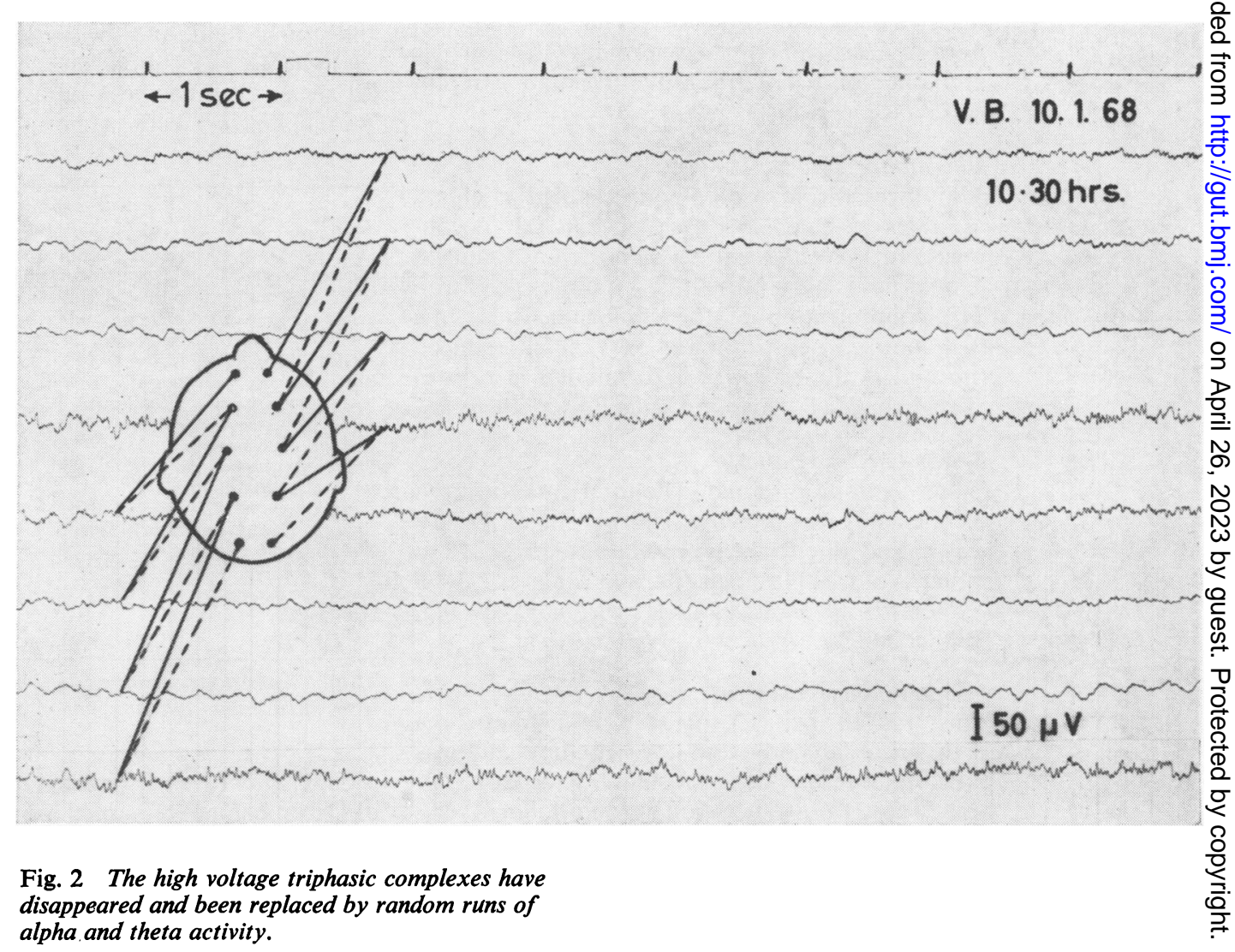


period of 36 hours. No drugs had been administered (in particular no phenothiaze derivatives).

Clinical examination on 7 January 1968 showed that she was only just responsive to painful stimuli. She was pyrexial (temperature $100^{\circ} \mathrm{F}$ ) and there had been a recurrence of oedema in the lower limbs but not of the ascites. The central venous pressure was normal but the pulse was irregular with an apex rate of $100 /$ minute. The blood pressure was $85 / 60$. There was a marked glossitis.

The neck was stiff but the Kernig sign was negative. The fundi were normal and the pupils responded to light. There was no ophthalmoplegia but the eyes showed dysconjugate 'wandering' movements. There was no trismus. Marked reflex pouting could easily be obtained.

There was no obvious paresis of the limbs, all of which, however, showed a gross increase in tone of extrapyramidal type. Grasp reflexes were readily elicited on each side. The upper limb tendon reflexes and knee jerks were symmetrically brisk but there was no clonus. The ankle jerks were sluggish. No plantar responses could be obtained.

An EEG (Fig. 1) was very abnormal. The record was dominated by diffuse, symmetrical, rhythmically repetitive sharp waves, many of which were triphasic. An ECG showed atrial fibrillation and ventricular complexes of low voltage, with non-specific ST depression. The total white count was $9,000 / \mathrm{mm}^{3}$ with a normal differential count. Blood cultures were sterile. The spinal fluid was clear, under normal pressure, and contained fewer than 5 cells $/ \mathrm{mm}^{3}$ and a protein of $50 \mathrm{mg} / 100 \mathrm{ml}$. The electrolyte pattern was abnormal and there was severe lactic acidosis (urea $34 \mathrm{mg} \%$; Na 137; K 2.9; $\mathrm{Cl} \mathrm{105;} \mathrm{HCO}_{3} 13$; and lactate $7 \cdot 3 \mathrm{~m}$-equiv/l). After appropriate intravenous therapy the electrolyte pattern returned to normal without any change in her general condition.

The neurological features were thought suggestive of the syndrome of 'nicotinic acid-deficiency encephalopathy'. Forty hours after admission the patient was given an intravenous injection of $100 \mathrm{mg}$ of nicotinamide. Within six hours a dramatic change took place. She became conscious and, although inattentive, was capable of responding to command, of smiling, of limited cooperation, and of some spontaneous speech. There was no nystagmus or ophthalmoplegia. The neck was much less stiff and there was no longer any reflex pouting although grasp reflexes could still be elicited. Power in the limbs was normal and the previously noted rigidity much reduced. She could not cooperate in the sensory examination but there was not gross deficit. A second EEG (Fig. 2), performed some 40 hours after the first, showed a dramatic change. The high voltage triphasic complexes had disappeared and had been replaced by random runs of alpha and theta activity over both hemispheres. A further intravenous injection of $100 \mathrm{mg}$ of nicotinamide was given and she was put on a high oral vitamin intake. The following day she was mentally alert with no residual neurological signs. A marked improvement in the glossitis was also noted.

\section{Discussion}

This patient was suffering from extensive smallintestinal diverticulosis with massive bacterial overgrowth which had led to steatorrhoea, creatorrhoea, hypoalbuminaemia, and malabsorption of vitamin $B_{12}$. These abnormalities responded to treatment with intravenous albumin and antibiotics. She also demonstrated a neurological syndrome, developing acutely during the recovery phase of her illness, which responded dramatically to intravenous nicotinamide. Although a wide variety of neurological symptoms have been described in patients with malabsorption due to jejunal diverticulosis, these are usually due to vitamin $B_{12}$ deficiency (Cooke, Cox, Fone, Meynell, and Gaddie, 1963), of which there was no evidence in our patient.

The grounds for making the diagnosis of encephalopathy due to nicotinamide deficiency were as follows. (1) There was a marked similarity between the clinical features exhibited (stupor, neck stiffness, generalized extrapyramidal rigidity, grasp reflexes, etc.) and those previously described in nicotinamide deficiency encephalopathy (Jolliffe et al, 1940. Spillane, 1947) (2) The clinical and electroencephalographic responses to specific therapy were rapid and complete. (3) The encephalopathic syndrome occurred in association with a severe glossitis. There was no evidence to suggest that the glossitis might have been due to iron or riboflavine deficiency. (4) There was a clinical background of severe malabsorption.

Cleckley et al (1939) pointed out that cerebral manifestations might be the first evidence of severe or complete depletion of nicotinic acid. 'Hebetude grading into profound stupor' might occur even when the usual clinical features of pellagra were absent. The authors described 19 stuporous patients showing remarkable improvement after intravenous nicotinic acid therapy. They stressed that such patients fell into a high mortality group, 'usually inadequately diagnosed as cerebromalacia, hospitalized as a gesture and perfunctorily treated until death from bronchopneumonia'. Jolliffe et al (1940) stressed that whereas nicotinic acid deficiency encephalopathy might occasionally be seen in endemic pellagrins, it was in fact more often encountered in chronic alcoholics or other malnourished individuals, particularly when such individuals developed acute intercurrent illnesses such as pneumonia, lung abscess, perforated ulcer, or subarachnoid haemorrhage. In such patients there may be none of the usual tell-tale signs of pellagra. Spillane 
(1947) points out that in localities where pellagra is not endemic the true nature of such nervous disturbances may pass unrecognized in the absence of the cutaneous signs of this disease. According to Jolliffe and his colleagues (1940), 'the encephalopathic syndrome represents complete nicotinic acid deficiency while the pellagra syndrome represents a partial deficiency. Patients showing the encephalopathic syndrome without signs of pellagra would represent a complete nicotinic acid deficiency which develops so rapidly that the structural changes in the mouth and skin characteristic of pellagra do not have time to occur.'

The mechanism(s) by which our patient could have developed nicotinamide deficiency is uncertain. The dietary intake was only minimally reduced. Since a proportion of dietary 1-tryptophan is normally converted to nicotinic acid and it is known that pellagra is more likely to occur if the intake or absorption of protein is poor (Truswell, Liadsky, Wittmann, and Hansen, 1962), the protein malabsorption, which was definitely present in our patient, may have played a part in the presumed nicotinamide deficiency.

Nicotinamide deficiency may also occur as a result of the deviation of dietary tryptophan into abnormal metabolic pathways. Pellagra, for instance, may complicate the carcinoid syndrome (Thörson and Nordenfelt, 1959) where there is a preferential conversion of 1-tryptophan into 5HIAA. It is also known that in patients with bacterial colonization of the small intestine a substantial proportion of the dietary tryptophan may be converted into indoles and excreted in the urine as indoxyl sulphate (indican). Our patient had massive bacterial contamination of the small bowel and marked indicanuria, which may have contributed to the nicotinamide deficiency.

Many species of intestinal bacteria are known to synthesize vitamins including nicotinic acid (Donaldson, 1964). It might be argued that in our patient such micro-organisms were playing a role in maintaining an adequate source of nicotinamide until they were eliminated or drastically reduced in number following tetracycline therapy. This type of mechanism has been described in relation to folic acid. Patients with massive bacterial colonization of the small intestine may show raised serum folate levels (derived from bacterial synthesis) and these levels may be abruptly lowered following antibiotic therapy (Hoffbrand, Tabaqchali, and Mollin, 1966). In our patient the intestinal flora was grossly abnormal and it is conceivable that the 'therapeutic' elimination of nicotinamide-synthesizing bacteria was sufficient to precipitate symptoms of acute nicotinamide deficiency.
Recently Raghuramulu, Srikantia, Rao, and Gopalan (1965) have shown that the synthesis in vitro of nicotinamide nucleotides by human erythrocytes could be significantly reduced by $\overline{\bar{s}}$ leucine. It has been known for several years that $\overline{0}$ the administration of leucine to pellagrins could precipitate mental symptoms (Gopalan and $\frac{\bar{F}}{\bar{T}}$ Srikantia, 1960). Such administration is often $\stackrel{\varnothing}{\varrho}$ associated with a deterioration in the EEG that cannot be related to any leucine-induced change $\rightarrow$ in the blood sugar level (Srikantia, Reddy, and. Krishnaswamy, 1968). It is just conceivable that $\overrightarrow{\vec{\omega}}$ the improved protein absorption in our patient $\stackrel{\mathscr{O}}{\mathscr{O}}$ achieved in hospital or the abnormal activity of bacteria in the bowel could have influenced $\stackrel{+}{\rightleftarrows}$ nicotinamide synthesis by a leucine-like effect.

We are grateful to Dr $O$. Neale for permission to publish this case.

\section{References}

Cleckley, H. M., Sydenstricker, V. P., and Geeslin, L. E. (1939). Nicotinic acid in the treatment of atypical psychotic states $\bar{\nabla}$ associated with malnutrition. J. Amer. med. Ass., 112, 覀 2107-2110.

Cooke, W. T., Cox, E. V., Fone, D. J., Meynell, M. J., and Gaddie, $\overrightarrow{0}$ R. (1963). The clinical and metabolic significance of jejunal $\oslash$ diverticula. Gut, 4, 115-131.

Donaldson, R. M., Jr. (1964). Normal bacterial populations of the intestine and their relation to intestinal function. New Engl.J. Med., 270, 994-1001.

Fordtran, J. S., Scroggie, W. B., and Polter, D. E. (1964). Colonic $\overline{\bar{O}}$ absorption of tryptophan metabolites in man. J. Lab. clin. బิ Med., 64, 125-132.

Gopalan, C., and Srikantia, S. G. (1960). Leucine and pellagra. Lancet, 1, 954-957.

Hines, J. D., Hoffbrand, A. V., and Mollin, D. L. (1967). The hematologic complications following partial gastrectomy. Amer. J. Med., 43, 555-569.

Hobbs, J. R., and Aw, S. E. (1968). Urinary Isoamylases (Enzymes in Urine and Kidney). Huber, Berne and Stuttgart.

Hoffbrand, A. V., Tabaqchali, S., and Mollin, D. L. (1966). High serum-folate levels in intestinal blind loop syndrome. Lancet, 1, 1339-1342.

Jolliffe, N., Bowman, K. M., Rosenblum, L. A., and Fein, H. D. (1940). Nicotinic acid deficiency encephalopathy. J. Amer. med. Ass., 114, 307-312.

Lewis, B., Panveliwalla, D., Tabaqchali, S. , and Wootton, I. D. P. (1969). Serum bile-acids in the stagnant-loop syndrome. Lancet, 1, 219-220.

Neale, G., Antcliff, A. C., Welbourn, R. B., Mollin, D. L., and Booth, C. C. (1967). Protein malnutrition after partial 음 gastrectomy. Quart. J. Med., 36, 469-494.

Raghuramulu, N., Srikantia, S. G., Rao, B. S. N., and Gopalan, N C. (1965). Nicotinamide nucleotides in the erythrocytes of $\sigma$ patients suffering from pellagra. Biochem. J., 96, 837-838. N

Spillane, J. D. (1947). Nutritional Disorders of the Nervous System. Livingstone, Edinburgh.

Srikantia, S. G., Reddy, M. V., and Krishnaswamy, K. (1968), Electroencephalographic patterns in pellagra. Electroenceph. clin. Neurophysiol., 25, 386. Sydenstricker, V. P. (1940). Personal communication. Quoted by
Jolliffe et al (1940).

Tabaqchali, S., Hatzioannou, J., and Booth, C. C. (1968). Bile salt deconjugation and steatorrhoea in the stagnant loop $T$ syndrome. Lancet, $2,12$.

Thörson, A., and Nordenfelt, O. (1959). Development of valvular lesions in metastatic carcinoid disease. Brit. Heart J., 21, 243-248.

Truswell, A. S., Liadsky, C., Wittmann, W., and Hansen, J. D. L. (1962). Are the skin lesions of kwashiorkor pellagrous? S. Afr. med. J., 36, 965-966. 